\title{
Scorpionism in Central America, with special reference to the case of Panama
}

Borges A (1, 2, 3, 4), Miranda RJ (4), Pascale JM (3)

(1) Laboratory of Molecular Biology of Toxins and Receptors, Institute of Experimental Medicine, Faculty of Medicine, Central University of Venezuela, Caracas, Venezuela; (2) Faculty of Medicine, University of Panama, Panama City, Republic of Panama; (3) Department of Genomics and Proteomics, Gorgas Memorial Institute for Health Studies, Panama City, Republic of Panama; (4) Department of Medical Entomology, Gorgas Memorial Institute for Health Studies, Panama City, Republic of Panama.

\begin{abstract}
Scorpionism in the Americas occurs mainly in Mexico, northern South America and southeast Brazil. This article reviews the local scorpion fauna, available health statistics, and the literature to assess scorpionism in Central America. Notwithstanding its high toxicity in Mexico, most scorpion sting cases in Guatemala, Belize, El Salvador, Nicaragua, and Costa Rica are produced by species in the genus Centruroides that are only mildly toxic to humans despite the existence of ion channel-active toxins in their venoms. Regional morbidity is low with the exception of Panama, where an incidence of 52 cases per 100,000 inhabitants was recorded for 2007, with 28 deaths from 1998 to 2006. Taxa belonging to the genus Tityus (also present in the Atlantic coast of Costa Rica) are responsible for fatalities in Panama, with Tityus pachyurus being the most important species medically. Most Tityus species inhabiting Panama are also found in northern South America from which they probably migrated upon closure of the Panamanian isthmus in the Miocene era. Incorporation of Panama as part of the northern South American endemic area of scorpionism is thereby suggested based on the incidence of these accidents and the geographical distribution of Panamanian Tityus species.
\end{abstract}

Key words: scorpionism, Central America, Tityus, Centruroides, scorpions.

\section{SCORPION ENVENOMATION IN THE AMERICAS}

Scorpionism, or the accidental envenomation of humans by toxic scorpions, is a global problem, but mainly restricted to tropical and subtropical areas. Most of the scorpions capable of inflicting deadly stings belong to the family Buthidae, the only exception being Hemiscorpius lepturus, in Iran (family Hemiscorpiidae) $(1,2)$. The syndrome derived from envenoming by toxic buthids is very complex. It usually involves cardiorespiratory complications that result from the direct and/or indirect effect of low molecular weight toxins on the gating mechanism of voltage-sensitive sodium (Nav) and potassium (Kv) channels and the subsequent release of neurotransmitters from presynaptic terminals and inflammatory mediators from affected tissues including the lung and pancreas $(1,3)$. Although the action mode of toxins targeting excitable tissues is very similar regardless of the scorpion species, clinical manifestations vary depending on the scorpion involved in the accident, as observed in South America (4). Higher molecular 
weight components, such as proteolytic and connective-tissue degrading enzymes (i.e. hyaluronidase) may contribute synergistically with neurotoxins to the pathophysiology of scorpion envenoming $(5,6)$.

As reviewed recently by Chippaux and Goyffon (7), the American continent encompasses several endemic areas of scorpionism with incidence rates at over 50 cases per 100,000 inhabitants, in Mexico and the southwestern United States, northern South America (including Ecuador, Colombia, Venezuela, and the Guianas) and southeast Brazil.

Probably due to the scarcity of data for the region, scorpionism in Central America had not previously been assessed despite several countries being inhabited by the genera Centruroides and Tityus, both of which contain species that have proven lethal to humans elsewhere in the Americas. For instance, six Centruroides species are highly toxic in Mexico (C. infamatus, C. limpidus limpidus, C. limpidus tecomanus, C. suffusus suffusus, C. noxius) and the United States (C. sculpturatus), while Tityus includes at least twenty species of medical importance throughout South America and the Caribbean, including $T$. discrepans, $T$. zulianus, and T. nororientalis (Venezuela), $T$. trinitatis (Trinidad and Tobago), T. pachyurus, T. asthenes, and T. fuhrmani (Colombia), T. serrulatus, T. stigmurus, and T. bahiensis (southeast Brazil), T. obscurus (formerly $T$. paraensis/T. cambridgei, Brazilian Amazon, French Guiana and Guyana), T. metuendus (the Peruvian and Brazilian Amazon), and T. trivitattus and $T$. confluens (Argentina) (4, 8-18).

In this paper, we endeavor to review the scorpionism problem in the Central American region with particular emphasis on Panama, where scorpion envenomation has acquired increasing epidemiological importance in recent years (19). The reasons for the restriction of lethal cases in Central America to the Panamanian isthmus are discussed in light of the biogeography and toxinology of Tityus and Centruroides species.

\section{THE CENTRAL AMERICAN SCORPION FAUNA}

According to the most recent accounts of the Central American scorpion fauna, 37 species inhabit the region, belonging to the families Buthidae (genera Ananteris, Centruroides, Tityus, and Isometrus), Chactidae (genera Broteochactas, Chactas, and Plesiochactas), Diplocentridae (genera Diplocentrus and Dydimocentrus), Hemiscorpiidae (genus Opistachanthus) and Vejovidae (genus Vejovis) $(20,21)$. Scorpions from the families Chactidae, Diplocentridae and Vejovidae are not considered noxious to humans and produce only localized symptoms upon accidental stings, as their species synthesize toxins that are mainly active against insects (e.g. Opisthacanthus cayaporum) and also cytotoxic peptides with the ability to form plasma membrane pores, which act as potent bactericides that prevent contamination of the venom gland $(22,23)$.

Epidemiological importance in the region is restricted to buthid scorpions in the genera Centruroides (Table 1) and Tityus (Table 2), with 12 and 8 species, respectively. Two species of the genus Centruroides are widely distributed in the region, namely $C$. margaritatus, found in six countries, and $C$. gracilis, found in four countries (Table 1). Both species also inhabit South America (24). There is controversy regarding the actual geographic distribution of C. margaritatus given that some Panamanian populations identified historically in this species have now been assigned to $C$. granosus (25). C. gracilis and C. margaritatus are followed in range of distribution by $C$. koesteri (three countries), C. limbatus (four countries) and C. schmidti (three countries). Some species are only known from their type locality, such as C. mahnerti and C. ochraceus. The evolutionary relationships of Centruroides species inhabiting Central America to those prevalent in Mexico, which are responsible for the severe scorpionism mainly in the Pacific area, have not been determined thus far.

The distribution of species from the genus Tityus range from the Darién region in Panama 
Table 1. Distribution of species belonging to the genus Centruroides in Central American countries

\begin{tabular}{|c|c|c|c|c|c|c|c|c|}
\hline $\begin{array}{l}\text { Centruroides } \\
\text { species }\end{array}$ & Guatemala & $\begin{array}{c}\text { El } \\
\text { Salvador }\end{array}$ & Honduras & Belize & Nicaragua & $\begin{array}{l}\text { Costa } \\
\text { Rica }\end{array}$ & Panama & $\begin{array}{l}\text { References and } \\
\text { comments }\end{array}$ \\
\hline C. bicolor & & & & & & $x$ & $x$ & $20,21,26,27$ \\
\hline C. exilimanus & $x$ & & $x$ & & & & & 28,29 \\
\hline C. fallassisimus & $x$ & & $x$ & & & & & 25 \\
\hline C. gracilis & $x$ & $x$ & $x$ & $x$ & & & & 28 \\
\hline C. granosus & & & & & & & $x$ & 25 \\
\hline C. koesteri & & & $x$ & & $x$ & $x$ & & $20,21,26,28$ \\
\hline C. limbatus & & & $x$ & & $\mathrm{x}$ & $\mathrm{x}$ & $x$ & $\begin{array}{c}20,21,26,30 \\
31\end{array}$ \\
\hline C. mahnerti & & & & & $x$ & & & $\begin{array}{l}\text { Armas \& Maes } \\
\text { (20) considered } \\
\text { this species } \\
\text { as a possible } \\
\text { synonym of } C \text {. } \\
\text { koesteri but did } \\
\text { not provide } \\
\text { reasons for it }\end{array}$ \\
\hline C. margaritatus & $\mathrm{x}$ & $x$ & $x$ & & $x$ & $\mathrm{x}$ & $x$ & $\begin{array}{c}20,21,26,27 \\
28\end{array}$ \\
\hline C. ochraceus & & & & $x$ & & & & 20,21 \\
\hline C. schmidti & $x$ & & $x$ & & $x$ & & & 28,32 \\
\hline C. tapachulaensis & $x$ & & & & & & & 33 \\
\hline
\end{tabular}

Table 2. Distribution of species belonging to the genus Tityus in Central American countries

\begin{tabular}{|c|c|c|c|c|c|c|c|c|}
\hline Tityus species & Guatemala & $\begin{array}{c}\text { El } \\
\text { Salvador }\end{array}$ & Honduras & Belize & Nicaragua & $\begin{array}{l}\text { Costa } \\
\text { Rica }\end{array}$ & Panama & $\begin{array}{l}\text { References and } \\
\text { comments }\end{array}$ \\
\hline T. asthenes & & & & & & $x$ & $x$ & $\begin{array}{l}26,27 \text { (as } T \text {. } \\
\text { championi) }\end{array}$ \\
\hline T. cerroazul & & & & & & $x$ & $x$ & $34-36$ \\
\hline T. dedoslargos & & & & & & $x$ & & 26 \\
\hline T. festae & & & & & & & $x$ & 27,37 \\
\hline T. ocelote & & & & & & $x$ & $x$ & 26,30 \\
\hline T. pachyurus & & & & & & $x$ & $x$ & 26,27 \\
\hline T. tayrona & & & & & & & $x$ & 38,39 \\
\hline
\end{tabular}

as far as northern Costa Rica, with two endemic Central American species: T. cerroazul (first described for Panama and also found in Costa Rica) and $T$. dedoslargos (inhabiting southern Costa Rica in the Punta Arenas province) (26, 34-36, 40). Until the present time, Tityus species in Central America have been identified only in Panama and Costa Rica, with each country having, respectively, six and five of the seven species described in this region (Table 2). Of these, four are shared with South American countries: T. pachyurus (Colombia), T. asthenes (Colombia, Ecuador and Peru), T. festae (Colombia), and T. tayrona (Colombia). Accounts of the Panamanian Tityus (and also Centruroides) fauna have been published recently $(38,39)$. 
Without doubt, T. pachyurus, a species described by Reginald Pocock from Colombia in 1897, is the most amply distributed and abundant Tityus in Central America. It belongs to the group of large-sized (60-100 mm in adults) dark scorpions in the subgenera Atreus, proposed by Lourenço (41) in his subdivision of Tityus, and was originally grouped, together with $T$. asthenes and T. festae, with other Amazonian and Colombian Tityus by Mello-Leitão (Group 'L') (42). In Central America T. pachyurus can be found from central Panama to southern Costa Rica (Figure 1). For biogeographical reasons yet to be elucidated, T. pachyurus exhibits a disjoint distribution given that the species is frequent in the neighboring Colombian departments of Antioquia and Chocó, but is unrecorded in eastern Panama, including the Darién region (14). The prevalent scorpion in this area is T. festae, first collected in Quintín (Darién) in 1899, and currently distributed up to central Panama (27, 37) (Figure 1). T. pachyurus is not sympatric with T. festae, at least in Central America (R. Miranda, personal observations) and the two species are distinguishable in appearance.
T. festae is the largest Panamanian Tityus, reaching 90 to $100 \mathrm{~mm}$ in adults, in comparison to T. pachyurus, which measures between 50 and $70 \mathrm{~mm}$, and T. asthenes (70-90 mm). It can also be distinguished by the significantly intense glow it presents when exposed to ultraviolet light (38).

T. asthenes is a much less abundant species in Panama compared to Colombia, where it is responsible for moderate and severe accidents in the department of Antioquia (13). This species can be found from Darién Province, in Panamá, up to Puntarenas Province, in Costa Rica (40) (Figure 1).

Most Central American Tityus taxa are clearly of South American origin, with the only exception being T. cerroazul, endemic to Panamá and Costa Rica. A preliminary molecular phylogenetic assessment suggests that T. pachyurus, T. festae, and T. asthenes are related to South American congeners inhabiting Colombia and western Venezuela (43; A. Borges, unpublished results) and that the probable ancestor of the extant Central American Tityus species populated these territories upon closure of the isthmus of Panama in the Miocene. T. cerroazul, on the contrary,

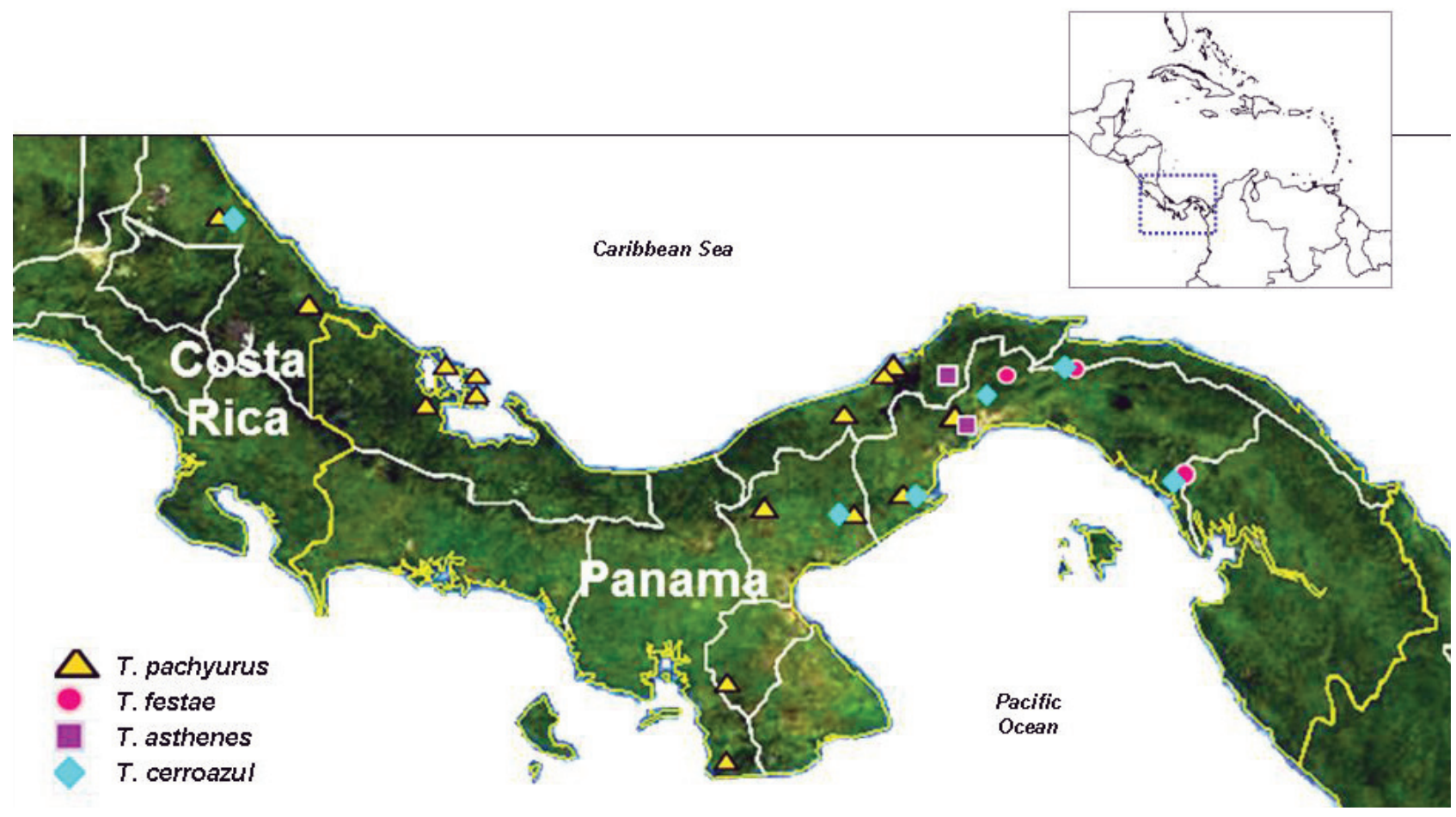

Figure 1. Geographical distribution of Central American Tityus species: The known distribution of T. asthenes, T. cerroazul, T. festae, and T. pachyurus in Panama and Costa Rica is presented with data taken from references 26, 27, 34-38, and 39. Unpublished data from R. Miranda, regarding additional collection localities for Tityus sp. in Panama are also included. 
represents a unique entity whose evolutionary relationships are yet to be determined, with its novelty further confirmed by the lack of reactivity of its toxins towards anti-Tityus antivenoms produced in Brazil and Venezuela. T. cerroazul is distributed throughout the provinces of Darién, Colón, Panama, and Coclé and is also found in southern Costa Rica $(36,38)$ (Figure 1).

\section{SCORPIONISM IN CENTRAL AMERICA}

Epidemiology of scorpionism in Central America is less documented compared to accidental bites by poisonous snakes. Although data are fragmentary, statistics from hospital records indicate that about 5000 snakebite cases are reported for the region annually (44). For the purpose of this review, local health/entomological authorities and/or the literature were consulted to evaluate the case-based evidence for scorpionism in each Central American country:

\section{Guatemala}

According to the Ministry of Public Health and Social Assistance, 38 scorpion sting cases were recorded for the period 2005-2010, with most of the cases ( $\mathrm{n}=22,57.8 \%$ ) corresponding to the department of Izabal, on the Guatemalan border with Belize and Honduras, in the Caribbean coastal region (T. S. Ana Maribel Sazo, Unit of Access to Public Information, Ministry of Public Health and Social Assistance of Guatemala, personal communication, 4/26/2011). Alacramyn ${ }^{\odot}$ antivenom, produced by Laboratorio Silanes, Mexico, against Mexican Centruroides species, is registered for use in Guatemala against scorpion stings (45). Centruroides margaritatus is the species most frequently associated with human dwellings, at least in the Motagua River Valley of Central Guatemala, although there are no records associating this species with envenomation cases in the country (46).

\section{Belize}

The most common scorpion in the country is Centruroides gracilis whose sting, although briefly painful, may produce aftereffects taking up to 24 hours to disappear completely (47). Accidents inflicted by scorpions on Dutch military personnel stationed in Belize during jungle training could be treated symptomatically in the field, which can also be taken to indicate the low toxicity of the local scorpion fauna (Dr. P.P.A.M. van Thiel, Consultant to the Surgeon General NL Armed Forces, Department of Infectious Diseases, Tropical Medicine and Aids, Academic Medical Center, University of Amsterdam, personal communication, 10/12/2011). No statistics are available on scorpion envenomation in the country.

\section{El Salvador}

For the period 2006-2011 the Ministry of Health reported 61 cases of scorpion envenomation with no fatalities (Epidemiological Surveillance, personal communication, 11/30/2011). Most patients were discharged after 48 hours of observation. Less than half of the victims were aged between 20 and 50 years $(n=29,47.5 \%)$. Stings predominantly occurred inside the domicile ( $\mathrm{n}$ $=32,52.4 \%)$. Most accidents took place in the provinces of La Unión $(n=21)$, Usulatán $(n=13)$, and San Miguel $(n=10)$, in the eastern section of the country. In La Unión province, on the border with Honduras, where the majority of accidents are reported, casualties have come from the villages of Bolívar, Pasquina and Santa Rosa de Lima, in the driest area of El Salvador. Anecdotal reports collected by Salvadoran entomologists note that only local manifestations such as pain and burning sensation are produced after envenomation by local species (M.Sc. Francisco Chicas Batres, School of Biology, Faculty of Natural Sciences and Mathematics, Universidad de El Salvador, personal communication). Alacramyn $^{\oplus}$ antivenom is also registered for use in El Salvador (45).

\section{Honduras}

Envenomation by scorpions as well as other arthropods is listed in the health records as "sting by unknown animal," making it difficult to assess the magnitude of the problem (Dr. Tomás Guevara, Director, Health Surveillance Division, Ministry of Health of Honduras, personal communication, 10/5/2011). We infer, however, that scorpion stings should be frequent in Honduras given the statistics reported by neighboring Nicaraguan and Salvadoran authorities.

\section{Nicaragua}

Envenomation is frequent although no systemic manifestations are recorded. A sting by Nicaraguan Centruroides sp. produces local 
pain, numbness of the tongue and paresthesia in hands and feet (Dr. Jean Michel Maes, Museo Entomológico, León, Nicaragua, personal communication, 9/25/2011). According to the Nicaraguan National Center of Toxicology (Dr. Luz Marina Lozano, Ministry of Health of Nicaragua, personal communication, $9 / 26 / 2011$ ), a total of 392 scorpion sting cases were recorded during the period 2005-2011, making it the leading envenoming invertebrate in the country, followed by accidents produced by bees $(n=73)$ and wasps $(n=36)$. The largest number of victims are aged between 16 and 30 (n $=153,39 \%)$. Most sting cases are reported from the southwest, in the province of Rivas $(n=226$, $57.7 \%$ ), on the border with Costa Rica, and also in the province of Managua $(\mathrm{n}=152,38.7 \%)$. No fatalities associated with scorpion stings were recorded during this period. Treatment generally involves analgesics and antihistamine whereas patients are usually discharged without further complications.

\section{Costa Rica}

No scorpion envenomation cases were recorded in Costa Rica for the period 20052010 (Dr. Gloria Trejos, Health Surveillance Department, Ministry of Health of Costa Rica, personal communication, 5/10/2011). However, Leveridge (48) reported that scorpion stings are frequent in the country and numbers have been increasing since 1992, with 24 cases that year. In 1998, 206 envenomations were reported to the National Center for Envenomation Control. In 1999, a total of 405 cases were recorded. The most frequent clinical manifestations were pain (44.7\%), numbness (26.7\%) and local inflammation (13.8\%). Most reported stings were from the capital's metropolitan area, including San José, Alajuela, Heredia and Cartago, with $91 \%$ of the accidents occurring in dwellings. These areas are known to be inhabited by Centruroides species, although no association has been reported between taxa and clinical outcome. No official records of envenomation have been reported from the Pacific or the Caribbean mountainous areas, inhabited by T. dedoslargos, T. asthenes and T. pachyurus.

\section{Panamá}

The Department of Epidemiology, Direction of Public Health, Ministry of Health, reports 9301 cases of scorpion envenomation for the period 2005-2009, with the largest number of cases ( $\mathrm{n}=$ $1955,21.2 \%)$ corresponding to the provinces of Coclé $(\mathrm{n}=539)$, Chiriquí $(\mathrm{n}=312)$, Panamá Oeste $(\mathrm{n}=302)$, and Colón $(\mathrm{n}=279)$ (Lic. Graciliana Chiari, Statistics and Surveillance Section, Epidemiology Department, Health Ministry of Panama, personal communication, 7/4/2011). Coronado et al. (19) reported 28 deaths, mostly in children (ages between 1 and 14 years), due to scorpion stings in the period 1998-2006, making Panama the only country in the region with fatalities due to scorpion envenomation. Scorpions involved in severe cases and fatalities have been positively identified as belonging to the genus Tityus while most of the cases with mild symptomatology are associated with stings by C. margaritatus (38). Main complications associated with scorpion sting by Tityus species are arterial hypertension (16.2\%), acute lung edema (5.7\%), and cardiac arrhythmias (3.9\%) with predominance of sinus bradycardia ( 5 cases out of 9) and ventricular tachycardia (2 out of 9 cases) (19).

\section{Exported Cases}

To the best of our knowledge, the only published clinical account of an envenomation by a Central American Centruroides is that of a 67-year-old woman stung by a C. limbatus specimen exported to California, United States (49). The sting produced local pain and systemic symptoms, including paresthesias, flushing, hypertension, and wheezing, as a result of reactive airway exacerbation and a mild allergic reaction.

\section{CENTRUROIDES ENVENOMATION IN THE AREAS SOUTH OF MEXICO}

Centruroides is one of four genera belonging to the Buthidae family in Central America, the others being Ananteris, Tityus, and Isometrus. Venom from buthid scorpions contains potent neurotoxins acting on vertebrate voltagesensitive sodium (Nav) and potassium (Kv) channels, which in the Americas have been isolated and characterized from Mexican species of Centruroides and South American Tityus responsible for severe scorpionism (for reviews see references 50 and 51), with the most toxic peptides for vertebrates being those targeting $\mathrm{Nav}$ channels (50). 
As described above in our review of scorpionism in Guatemala, Belize, El Salvador, Nicaragua and Costa Rica, the Central American Centruroides relatives of noxious North American species do not produce venoms that are lethal to vertebrates as indicated by the relatively mild symptomatology reported in envenomed humans. The accident by $C$. limbatus described by Bush (49) was classified as grade II envenomation based on the C. sculpturatus grades of envenomation defined by Curry et al. (9) in Central Arizona and confirms the mildness of scorpionism cases in Central American countries where C. limbatus and related species are endemic.

Centruroides envenomation elsewhere in the Americas also appears to be mild. In an accident that took place at São Paulo International Airport involving a $C$. testaceus specimen from the Netherland Antilles, a six-year-old girl only presented erythema and pain at the site of the sting (52). Marinkelle and Stahnke (53) also reported that the most common and important symptoms in a series of 31 patients envenomed by $C$. margaritatus in Colombia were pain, local edema and fever one to 20 hours after the sting. Reinforcing these data from humans, Marinkelle and Stahnke (53) determined that C. margaritatus venom from Cali, Colombia, presents low toxicity for mice, with an LD50 of $59.9 \mathrm{mg} / \mathrm{kg}$, which was later confirmed by Guerrero-Vargas et al. (54) with another Colombian population of this species from the Patía Valley, department of Cauca (LD50 $=42.8$ $\mathrm{mg} / \mathrm{kg}$ ). However, a conflicting report indicating an LD50 of $5 \mathrm{mg} / \mathrm{kg}$ has been registered also for C. margaritatus from Colombia (13).

The basis for such variations in toxicity across the distribution range of Centruroides is currently unknown. It would be of interest to determine the phylogenetic relationship of Centruroides species outside Mexico to those prevalent in that country in order to provide a framework for the study of variations in venom composition and activity across the genus that could explain such abrupt change in toxicity. The possibility exists that several evolutionary lineages exist within this scorpion group. Since the most toxic peptides in scorpion venoms towards vertebrates are those targeting $\mathrm{Nav}$ channels, it can be hypothesized that Central American Centruroides produce toxin variants directed at these channels that are of lower potency in vertebrates or, alternatively, that such toxins are produced at a lower abundance (50).

Nevertheless, toxins have been studied from C. limbatus and C. margaritatus that target $\mathrm{Kv}$ channels. For instance, C. limbatus hongotoxin (HgTX1), a 39-amino acid peptide, inhibits Kv1.1, Kv1.2, and Kv1.3 channels with equivalent high potency, but displays lower affinity for the Kv1.6 isoform (55). Similarly to HgTX1, C. margaritatus margatoxin (MgTX), a peptide with $89 \%$ amino acid sequence homology to hongotoxin specifically inhibits Kv1.3 channels, which are predominantly expressed in $\mathrm{T}$ lymphocytes. MgTX has been used as a tool to study activation in this cell population, since it inhibits the intracellular production of Th-1 as well as Th-2 cytokines (56). While these toxins have proven useful in the characterization of ion channels expressed in immune cells, their actual role in the envenomation process and their abundance in the venoms remain unknown. In this sense, a thorough toxinological study is pending on the Central American Centruroides species to assess the diversity and toxicity of their venom components in relation to their North American congeners. Only the study of Guerrero-Vargas et al. has addressed this point but using venom from a Colombian population of C. margaritatus, showing that toxins present in this venom are able to inhibit contraction of amphibian gastrocnemius muscle (54).

\section{CENTRUROIDES VERSUS TITYUS ENVENOMATION}

Scorpion stings of medical relevance in Central America involve species of Centruroides and Tityus, and it is also the objective of this review to compare both envenomation syndromes.

Most documented cases of scorpionism by Centruroides species come from Mexico and the United States. In the case of envenomation by $C$. sculpturatus in the southwestern United States, systemic envenomation may be associated with hypersalivation and respiratory distress. Serious adrenergic effects, however, are rare with $C$. sculpturatus envenomation; symptomatology is mainly cholinergic $(9,57)$. In three cases of $C$. sculpturatus envenomation, atropine's reversal of hypersalivation and respiratory distress obviated the need for further interventions (57). Atropine can dry secretions but is not 
recommended for stings from other buthid scorpions, since it exacerbates adrenergic toxicity to the cardiopulmonary system (57).

In the case of Mexican Centruroides species, a combination of adrenergic and cholinergic manifestations has been reported (8). However, at least in the case of $C$. limpidus tecomanus from Colima, there appears to be a predominance of parasympathomimetic effects since the most common symptoms included local paresthesia (67.2\%), pruritus/itching (54.3\%), globus hystericus $(47.3 \%)$, sialorrhoea $(27.7 \%)$, and restlessness (26.4\%) (58). Significantly, vomiting was observed in only $8.7 \%$ of the patients, which is in contrast to envenomation by Tityus species from Brazil and Argentina $(18,59)$. As mentioned above, accidents with Centruroides species outside Mexico and the southwestern United States only involve local manifestations.

On the contrary, envenomation by species belonging to the genus Tityus (with the exception of those pertaining to the subgenus Archaeotityus such as T. parvulus) invariably involves severe systemic manifestations, particularly in children, both of adrenergic and cholinergic nature (59). In southeast Brazil, envenomation by Tityus serrulatus mainly entails autonomic manifestations, with few or no neurological effects, whereas accidents involving Tityus cambridgei in Pará, northeastern Brazil, typically presents with central neurotoxicity (e.g., myoclonia, dysmetria, dysarthria, and ataxia) (16). Central American Tityus produces a syndrome reminiscent of the envenomation by Colombian and western Venezuelan Tityus belonging to the "asthenes" group described by Mello-Leitão (42), where cardiorespiratory complications are frequent $(13,60,61)$. In the series of patients reported by Coronado et al. (19) from Panama the predominant general signs and symptoms were vomiting $(42.8 \%)$, increase in respiratory rate (19.2\%), and sweating (14.8\%). The main complications of scorpion sting by local Tityus species were arterial hypertension (16.2\%) and pulmonary edema (5.7\%).

In spite of the fact that scorpion venoms act on excitable tissues in similar fashion regardless of the geographical origin of the species, differences have been noted between envenomation syndromes from different endemic areas (4). It is possible that such differential activity between Tityus and Centruroides venoms could be due, at least in part, to the facts that neurotoxins affecting Nav channels distinguish between tissue-specific isoforms of the channel and that neurotoxins with different specificities have been isolated from species of these genera, probably as a result of their evolutionary/ecological divergence $(62,63)$.

Very little is known about Tityus envenomation and its clinical consequences in Costa Rica, the other Central American country inhabited by this genus. Despite the original belief that no dangerous scorpions inhabited the country, the report of a girl severely envenomed by a scorpion in a region bordering the Chiriquí province of Panama (Dr. J.M. Gutiérrez, Instituto Clodomiro Picado, personal communication, $4 / 8 / 2009$ ) raises the possibility that similar accidents may take place in the future in Costa Rica (64). Gómez et al. (65) presented a preliminary characterization of the venom from the Costa Rican population of T. asthenes, which reported an LD50 in mice of $4.14 \mathrm{mg} / \mathrm{kg}$, higher than the lethality published for other congeneric species (66).

\section{SCORPION ENVENOMATION IN PANAMA}

It was long thought that scorpion envenomation did not represent a medical problem in Panama, mainly due to the fact that the most densely populated areas of the country, on the Pacific versant, overlapped with the distribution areas of C. margaritatus, whose envenomation only involves local symptomatology $(38,67)$. The naturalist William J. Baerg first described the envenomation by this species when he stung himself with a specimen collected in the former Canal Zone: "the resulting pain was weak and disappeared in a few minutes" (68). However, in the late 1990s a different picture emerged as several reports of severe and lethal envenomation cases from the Colón area were made. The entomologist Eustorgio Méndez, formerly at the Memorial Gorgas Institute in Panama, was the first to report that the species involved in these accidents was Tityus pachyurus (69).

Of the six Tityus species inhabiting Panama, $T$. pachyurus, T. asthenes, T. festae, and T. cerroazul (Figure 2) have been implicated in severe envenomation cases. T. tayrona (misidentified as T. parvulus), which belongs to the subgenus Archeotityus, has been wrongly classified as 

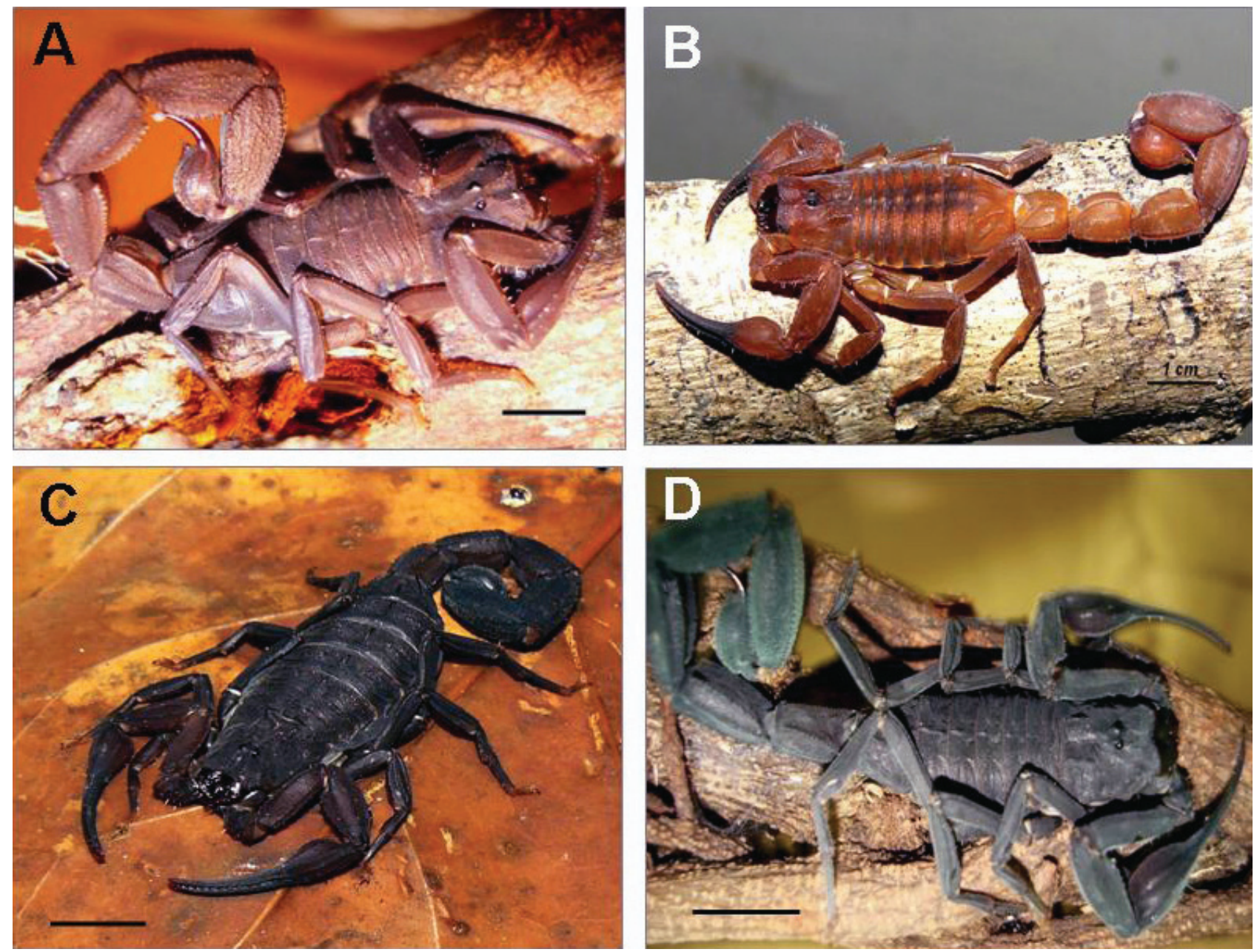

Figure 2. Species that belong to the genus Tityus responsible for severe scorpionism in Panama. (A) $T$. asthenes Pocock; (B) T. cerroazul Lourenço; (C) T. pachyurus Pocock; (D) T. festae Borelli (A: picture by A. Borges; B-D: pictures by R. Miranda). Bars are equivalent to $1 \mathrm{~cm}$ of length.

dangerous (19), as members of this scorpion group are regarded elsewhere to be of little medical importance (70). Recently, a 5-yearold girl died after being stung by $T$. festae in the region of Chepo, El Llano-Cartí, west of the province of Panama (Dr. L. Coronado, personal communication, 10/11/2010), and a 6-year-old boy died after being envenomed by T. cerroazul at Quebrada Amarilla, La Mesa del Valle de Antón, province of Coclé (28). T. pachyurus, T. asthenes, and $T$. festae are difficult to distinguish, all being of dark complexion. T. cerroazul, on the contrary, is clearly distinguishable by its light cinnamon coloration. By its complexion the latter can be confused with $C$. margaritatus, known locally as "chocolate" scorpion although these species are not sympatric, at least in Panama.

T.pachyurus, with its disjoint distribution, is the species responsible for most severe envenomation cases in central and western Panama, particularly among children in urban and forest areas of the provinces of Chiriquí, Coclé, Colón, and Panama (68). It can be hypothesized that the growth of some of the Panamanian cities into former forest areas of the central mountain ranges has involved land and vegetation removal which, together with garbage accumulation, have given rise to the appearance of toxic scorpions around and inside human dwellings as has been documented in other countries (71). Other regions such as Bocas del Toro are likely to become endemic in light of the reports of $T$. pachyurus inhabiting the areas where tourist and industrial activities are increasing (30). An incidence of 52 cases per 100,000 inhabitants was recorded for 2007 in Panama (72), surpassed only by Mexico (250 cases per 100,000 inhabitants) amongst Latin American countries affected by scorpionism (73). 
Anti-Tityus discrepans antivenom (Biotecfar, Faculty of Pharmacy, Central University of Venezuela, Caracas) is used throughout Panama for the treatment of scorpion envenomation $(19,67)$. In a recent survey to test the in vitro efficacy (using immunoblotting and ELISA) of antivenoms available in Latin America, including the Venezuelan serum, it was shown that the Brazilian (anti-T. serrulatus) and Mexican (anti-Centruroides) antivenoms presented poor recognition of the toxic fraction $(6-8 \mathrm{kDa})$ of Panamanian Tityus venoms (74). The Venezuelan antivenom weakly recognized such fractions in T. pachyurus, T. festae, and T. asthenes. Neither the Venezuelan nor the remaining antivenoms reacted with the low molecular weight proteins produced by $T$. cerroazul, which has at least produced one death in Panama $(35,74)$. Significantly, the Venezuelan antivenom has been shown to be ineffective against the experimental envenomation produced by Colombian $T$. pachyurus in mice (12). These results suggest the need for preparing new antiscorpion sera that effectively neutralize toxins from all local species and, if possible, also those from Costa Rican and Colombian populations. In Colombia, the anti-Centruroides Alacramyn ${ }^{\otimes}$ antivenom is used in some endemic areas of the country ( $R$. Otero, personal communication, 4/10/2010). The disjoint distribution of T. pachyurus, which is reported in the provinces of Chocó and Antioquia in Colombia but apparently lacking in Darién, posits the important question of whether Colombian and Central American $T$. pachyurus populations share common venom components and to what extent antigenic crossreactivity would allow neutralization of toxins from all geographical populations with the use of a single antivenom.

\section{CONCLUDING REMARKS}

The incorporation of Panama, and probably Costa Rica, as part of the previously recognized northern South American endemic area of scorpionism is thereby suggested based on the incidence of these accidents and the geographical distribution of Central American Tityus species (7). Taking into account the need for newly anti-Tityus antivenoms effective in both Central America and Colombia and given the taxonomical and toxinological complexity of the genus throughout its distribution range as well as the similarities of Central American Tityus to Colombian and western Venezuelan species, the preparation of such sera should be preceded by a study incorporating multiple criteria $(4,27,41)$. These criteria should extend beyond incidence/ species range, in order to determine whether regional or pan-regional sera are to be prepared. Such evidentiary aspects as the phylogenetic relationships, venom immunological crossreactivity and clinical manifestations associated with envenomation have been used previously for grouping the toxic scorpion fauna of Venezuela into toxinological provinces for guiding health authorities in the design of preventive and therapeutic measures against scorpionism (4). Implementation of a similar approach in the case of Central American Tityus should be helpful in guiding the preparation of antivenoms with the broadest possible spectrum of neutralization. Although envenomation by Central American Centruroides, well characterized taxonomically, does not represent a medical emergency in the region, the molecular basis for the differences in toxicity across the genus remains a subject open to future investigations $(25,26,28,29,31,33$, 38-40).

\section{NOTE ADDED IN PROOF}

Since this review was submitted for publication, Guerrero-Vargas et al. (75) have since published an account of the toxins produced by a Colombian population of $T$. pachyurus and the Amazonian scorpion $T$. obscurus. A phylogenetic assessment of the evolutionary relationship of these toxins to those produced by other congeners in the continent have revealed a strong separation between Tityus species inhabiting north of the Amazon Basin and those living in southern South America. This corroborates our statement asserting a close affinity of Central American Tityus to Colombian and western Venezuelan species and the observation of poor antigenic reactivity of their toxins towards antisera prepared against Brazilian Tityus species.

\section{ACKNOWLEDGEMENTS}

A. Borges contributed to this research during his sabbatical leave from Universidad Central de Venezuela while a Visiting Professor at the Faculty of Medicine, Universidad de 
Panamá, and a Visiting Scientist at the Instituto Conmemorativo Gorgas de Estudios de La Salud (ICGES), Panamá, both at the Department of Genomics and Proteomics and the Department of Medical Entomology. Thanks are conveyed to ProfessorHildaura Acosta dePatiño(Universidad de Panamá) for help with logistics during execution of grants SUM08-005 and COL10045. We are grateful to Dr. Rebecca Smith from ICGES for her critical review of the manuscript. We are also grateful to the following experts for their help in locating regional information: $T$. S. Ana Maribel Sazo, from Unidad de Acceso a la Información Pública, Ministry of Public Health and Social Assistance of Guatemala; M. Sc. Francisco Chicas Batres, School of Biology, Faculty of Natural Sciences and Mathematics, Universidad de El Salvador; Dr. Luz Marina Lozano, Centro Nacional de Toxicología, Sistema de Vigilancia Epidemiológica, Ministry of Health of Nicaragua; Dr. Jean Michel Maes, Entomological Museum, León, Nicaragua; Dr. Gloria Trejos, Health Surveillance Department, Ministry of Health of Costa Rica; Dr. P. P. A. M. van Thiel, Department of Infectious Diseases, University of Amsterdam, The Netherlands. Thanks are conveyed to Ingrid Murgas (Instituto Conmemorativo Gorgas de Estudios de la Salud) for her help with generation of distribution maps and Stephany Arizala (Universidad de Panamá) for her collaboration with management of the scorpion collection at ICGES. Financial help from SENACYT through projects SUM08-005 and COL10-045 is gratefully acknowledged.

\section{COPYRIGHT}

(C) CEVAP 2012

\section{SUBMISSION STATUS}

Received: January 5, 2012.

Accepted: February 29, 2012.

Abstract published online: March 6, 2012.

Full paper published online: May 31, 2012.

\section{CONFLICTS OF INTEREST}

The authors declare no conflicts of interest.

\section{FINANCIAL SOURCE}

Secretaría Nacional de Ciencia, Tecnología e Innovación (SENACYT) from Panama is gratefully acknowledged for financial support through research grants SUM08-005 and COL10045, whose goals inspired this review.

\section{CORRESPONDENCE TO}

Adolfo Borges, Instituto de Medicina Experimental, Facultad de Medicina, Universidad Central de Venezuela, Apartado Postal 50587, Caracas 1050, Venezuela. Phone: +58212 6053608. Fax: +58212 6628877. Email: borges. adolfo@gmail.com.

\section{REFERENCES}

1. Amitai Y. Scorpions. In: Brent J, Wallace KL, Burkhart KK, Phillips SB, Donovan JW, editors. Critical Care Toxicology. Maryland Heights: Elsevier Mosby; 2005. 1213-20 p.

2. Pipelzadeh $\mathrm{MH}$, Jalali A, Taraz M, Pourabbas R, Zaremirakabadi A. An epidemiological and a clinical study on scorpionism by the Iranian scorpion Hemiscorpius lepturus. Toxicon. 2007;50(7):984-92.

3. Martin-Eauclaire MF, Couraud F. Scorpion neurotoxins: effects and mechanisms. In: Chang LW, Dyer RS, editors. Handbook of neurotoxicity. New York: Marcel Drekker; 1995. 683-716 p.

4. Borges A, Rojas-Runjaic FJ, Diez N, Faks JG, Op den Camp HJ, De Sousa L. Envenomation by the scorpion Tityus breweri in the Guayana Shield, Venezuela: report of a case, efficacy and reactivity of antivenom, and proposal for a toxinological partitioning of the Venezuelan scorpion fauna. Wilderness Environ Med. 2010;21(4):282-90.

5. Fletcher PL Jr, Fletcher MD, Weninger K, Anderson TE, Martin BM. Vesicle-associated membrane protein (VAMP) cleavage by a new metalloprotease from the Brazilian scorpion Tityus serrulatus. J Biol Chem. 2010;285(10):7405-16.

6. Pessini AC, Takao TT, Cavalheiro EC, Vichnewski W, Sampaio SV, Giglio JR, et al. A hyaluronidase from Tityus serrulatus scorpion venom: isolation, characterization and inhibition by flavonoids. Toxicon. 2001;39(10):1495-504.

7. ChippauxJP, Goyffon M. Epidemiology of scorpionism: a global appraisal. Acta Trop. 2008;107(2):71-9.

8. Dehesa-Dávila M, Possani LD. Scorpionism and serotherapy in Mexico. Toxicon. 1994;32(9):1015-8.

9. Curry SC, Vance MV, Ryan PJ, Kunkel DB, Northey WT. Envenomation by the scorpion Centruroides sculpturatus. J Toxicol Clin Toxicol. 1983;21(4-5):41749.

10. Borges A, De Sousa L. Una aproximación multidisciplinaria para el estudio del envenenamiento por arácnidos en Venezuela. In: Arrivillaga J, El Souki M, Herrera B, editors. Enfoques y temáticas en entomología. Caracas: Ediciones Astrodata; 2009. 137-53 p.

11. Daisley H, Alexander D, Pitt-Miller P. Acute myocarditis following Tityus trinitatis envenoming: 
morphological and pathophysiological characteristics. Toxicon. 1999;37(1):159-65.

12. Barona J, Otero R, Núñez V. Toxicological and immunological aspects of scorpion venom (Tityus pachyurus): neutralizing capacity of antivenoms produced in Latin America. Biomedica. 2004;24(1):429.

13. Gómez JP, Quintana JC, Arbeláez P, Fernández J, Silva JF, Barona J, et al. Tityus asthenes scorpion stings: epidemiological, clinical and toxicological aspects. Biomedica. 2010;30(1):126-39.

14. Gómez JP, Otero R. Ecoepidemiología de los escorpiones de importancia médica en Colombia. Rev Fac Nac Salud Pública. 2007;25(1):50-60.

15. Lourenço WR. Scorpions of Brazil. Paris: Les Éditions l'If ; 2002. $307 \mathrm{p}$.

16. Pardal PP, Castro LC, Jennings E, Pardal JS, Monteiro MR. Epidemiological and clinical aspects of scorpion envenomation in the region of Santarém, Pará, Brazil. Rev Soc Bras Med Trop. 2003;36(3):349-53.

17. de Roodt AR, Lago NR, Salomón OD, Laskowicz RD, Neder de Román LE, López RA, et al. A new venomous scorpion responsible for severe envenomation in Argentina: Tityus confluens. Toxicon. 2009;53(1):1-8.

18. de Roodt AR, Coronas FI, Lago N, González ME, Laskowicz RD, Beltramino JC, et al. General biochemical and immunological characterization of the venom from the scorpion Tityus trivittatus of Argentina. Toxicon. 2010;55(1-2):307-19.

19. Coronado L, Alvarado M, Dutari JE. Características clínicas y epidemiológicas del Alacranismo. Período 2002-2007. Hospital del Niño, Panamá. Pediátr Panamá. 2008;37(2):36-46.

20. de Armas LF, Maes JM. Lista anotada de los alacranes (Arachnida: Scorpiones) de América Central, con algunas consideraciones biogeograficas. Rev Nicar Entomol. 1998; 46(1):23-38.

21. de Armas LF, Maes JM. Enmiendas a la "lista anotada de los alacranes de América Central (Arachnida: Scorpiones)". Cocuyo. 2001;10(1):16-7.

22. Schwartz EF, Camargos TS, Zamudio FZ, Silva LP, Bloch C Jr, Caixeta F, et al. Mass spectrometry analysis, amino acid sequence and biological activity of venom components from the Brazilian scorpion Opisthacanthus cayaporum. Toxicon. 2008;51(8):1499508.

23. Gao B, Tian C, Zhu S. Inducible antibacterial response of scorpion venom gland. Peptides. 2007;28(12):2299305.

24. Sissom WD, Lourenço WR. The genus Centruroides in South America (Scorpiones: Buthidae). J Arachnol. 1987;15(1):11-28.

25. de Armas LF, Trujillo RE. Nueva especie de Centruroides Marx, 1890 (Scorpiones: Buthidae) de Guatemala y Honduras, América Central. Bol SEA. 2010;47(1):235-40.

26. Francke OF, Stockwell SA. Scorpions (Arachnida) from Costa Rica. Special Pub Texas Tech Univ. 1987;25(1):1-64.

27. Lourenço WR, Méndez E. Inventario preliminar sobre la fauna de escorpiones de Panamá, con algunas consideraciones taxonómicas y biogeográficas. Rev Biol Trop. 1984;32(1):85-93.

28. Teruel R, Stockwell SA. A revision of the scorpion fauna of Honduras, with the description of a new species (Scorpiones: Buthidae, Diplocentridae). Rev Ibérica Aracnol. 2002;6(1):111-27.

29. de Armas LF, Viquez C. Primeros registros de Centruroides exilimanus Teruel \& Stockwell, 2001 (Scorpiones: Buthidae) para Guatemala y El Salvador, con la descripción de la hembra adulta. Bol SEA. 2005;37(1):169-70.

30. Armas LF, Montoya M. Escorpiones (Arachnida) del Archipiélago de Bocas del Toro, Panamá. Rev Biol Trop. 2002;50(1):155-60.

31. de Armas LF. Registro más septentrional del alacrán centroamericano Centruroides limbatus (Pocock, 1898) (Scorpiones: Buthidae) Rev Ibér Aracnol. 2003;7(1):101-2.

32. de Armas LF, Montoya M, Víquez C. Centruroides schmidti (Scorpiones: Buthidae) in Costa Rica. Rev Biol Trop. 2002;50(1):169-71.

33. de Armas LF, Trujillo RE, Viquez C, Agreda EO. Primer registro de Centruroides tapachulaensis Hoffmann, 1932 (Scorpiones: Buthidae) para Guatemala. Bol SEA. 2010;46(1):261-6.

34. Lourenço WR. Tityus cerroazul, nouvelle espèce de scorpion de Panamá (Scorpiones, Buthidae). Bull Mus Natl Hist Nat Sect A: Zool Biol Ecol Anim. 1986;8(3):637-41.

35. Quintero AD, Miranda RJ. Tityus cerroazul Lourenço (Scorpiones: Buthidae): nueva sinonimia, notas sobre su biología, nuevos registros de distribución en Panamá, descripción del macho previamente desconocido y picadura mortal de un niño. Tecnociencia. 2007;9(2):121-35.

36. Viquez C, de Armas LF, Lourenço WR. Presencia de Tityus cerroazul Lourenço, 1986 (Scorpiones: Buthidae) en Costa Rica y descripción del macho. Bol SEA. 2005;36(1):93-6.

37. Borelli A. Scorpioni raccolti nel Darien dal Dott. E. Festa. Bol Mus Zool Anat Comp Univ Torino. 1899;14(338):1-3.

38. Miranda R. Aspectos biológicos. In: Borges A, editor. Los escorpiones y el escorpionismo en Panamá. Panamá: Editora NovoArt; 2011. p. 13-20. 1 vol.

39. Teruel R, Cozijn MAC. A checklist of the scorpions (Arachnida: Scorpiones) of Panama, with two new records. Euscorpius. 2011;133(1): 1-6.

40. Víquez C. Escorpiones de Costa Rica. Santo Domingo, Heredia: Instituto Nacional de Biodiversidad (INBio); 1999. $84 \mathrm{p}$.

41. Lourenço WR. Nouvelle proposition de découpage sous-générique du genre Tityus C.L. Koch, 1836 (Scorpiones, Buthidae). Bol SEA. 2006;39:55-67.

42. Mello-Leitão C. Escorpiões sul-americanos. Arq Museu Nac. 1945;40(1):1-468.

43. Borges A, Bermingham E, Herrera N, Alfonzo MJ, Sanjur OI. Molecular systematics of the neotropical scorpion genus Tityus (Buthidae): the historical biogeography and venom antigenic diversity of toxic Venezuelan species. Toxicon. 2010;55(2-3):436-54. 
44. Gutiérrez JM. El envenenamiento ofídico en centroamérica. In: Organización Panamericana de la Salud, editors. Consulta técnica sobre accidentes con animales ponzoñosos en latinoamérica. São Paulo: OPS; 2007. 27 p.

45. Rosales-Mejía J. Desarrollo de antivenenos biotecnológicos [Internet]. In: Proceedings, XV Congreso Nacional de Urgencias y Emergencias Pediátricas, Querétaro, México. 2009. Available from: http://web.mac.com/kiky/MEMORIAS\%20XV\%20 CONGRESO\%20NACIONAL\%20URGENCIAS\%20 PEDIATRICAS-QUERETARO/47.\%20USO\%20 DE\%20FABOTERAPICOSm.pdf.

46. Trujillo Sosa RE. Impacto del cambio de uso del suelo sobre la diversidad de alacranes (Arachnida: Scorpiones) en el monte espinoso de la cuenca del río Motagua. [master's thesis]. Guatemala: Universidad de San Carlos de Guatemala; 2009. 68 p.

47. Meerman J. Some interesting invertebrates from Belize [Internet]. Belize: Biological-diversity.info; 20022005 [updated 2004 Dec 11]. Available from: http:// biological-diversity.info/ invertebrates.htm.

48. Leveridge Y. Accidente y cuadro clínico por la «picadura» de alacranes en Costa Rica. Rev Costarric Cienc Méd. 2000;21(3-4):161-7.

49. Bush SP. Envenomation by the scorpion (Centruroides limbatus) outside its natural range and recognition of medically important scorpions. Wilderness Environ Med. 1999;10(3):161-4.

50. Rodríguez de la Vega RC, Schwartz EF, Possani LD. Mining on scorpion venom biodiversity. Toxicon. 2010;56(7):1155-61.

51. Cologna CT, Marcussi S, Giglio JR, Soares AM, Arantes EC. Tityus serrulatus scorpion venom and toxins: an overview. Protein Pept Lett. 2009;16(8):92032.

52. Lobo RA, Goldoni PAM, Souza CAR, Medeiros CR. Acidente causado por Centruroides testaceus (DeGeer, 1778) (Scorpiones, Buthidae), nativo do Caribe, em aeroporto brasileiro. Rev Soc Bras Med Trop. 2011;44(6):789-91.

53. Marinkelle CJ, Stahnke HL. Toxicological and clinical studies on Centruroides margaritatus (Gervais), a common scorpion in western Colombia. J Med Entomol. 1965;2(2):197-9.

54. Guerrero-Vargas JA, Ayerbe S, Rada-Mendoza M, Vélez P, Beltran J, D'Suze G, et al. Preliminary toxinological characterization of the venom of the scorpion Centruroides margaritatus (Buthidae, Gervais, 1841) of the valle of the Patía, Colombia. J Venom Anim Toxins incl Trop Dis. 2007;13(1):228.

55. Koschak A, Bugianesi RM, Mitterdorfer J, Kaczorowski GJ, Garcia ML, Knaus HG. Subunit composition of brain voltage-gated potassium channels determined by hongotoxin-1, a novel peptide derived from Centruroides limbatus venom. J Biol Chem. 1998;273(5):2639-44.

56. Shah K, Tom Blake J, Huang C, Fischer P, Koo GC. Immunosuppressive effects of a Kv1.3 inhibitor. Cell Immunol. 2003;221(2):100-6.

57. Suchard JR, Hilder R. Atropine use in Centruroides scorpion envenomation. J Toxicol Clin Toxicol. 2001;39(6):595-8.

58. Chowell G, Díaz-Dueñas P, Bustos-Saldaña R, Mireles AA, Fet V. Epidemiological and clinical characteristics of scorpionism in Colima, Mexico (2000-2001). Toxicon. 2006;47(7):753-8.

59. Freire-Maia L, Campos JA, Amaral CF. Approaches to the treatment of scorpion envenoming. Toxicon. 1994;32(9):1009-14.

60. Otero R, Navío E, Céspedes FA, Núñez MJ, Lozano L, Moscoso ER, et al. Scorpion envenoming in two regions of Colombia: clinical, epidemiological and therapeutic aspects. Trans R Soc Trop Med Hyg. 2004;98(12):742-50.

61. Mazzei de Dàvila CA, Dàvila DF, Donis JH, Bellabarba GA, Villarreal V, Barboza JS. Sympathetic nervous system activation, antivenin administration and cardiovascular manifestations of scorpion envenomation. Toxicon. 2002;40(9):1339-46.

62. Schiavon E, Sacco T, Cassulini RR, Gurrola G, Tempia F, Possani LD, et al. Resurgent current and voltage sensor trapping enhanced activation by a beta-scorpion toxin solely in Nav1.6 channel. Significance in mice Purkinje neurons. J Biol Chem. 2006;281(29):2032637.

63. Leipold E, Hansel A, Borges A, Heinemann SH. Subtype specificity of scorpion beta-toxin Tz1 interaction with voltage-gated sodium channels is determined by the pore loop of domain 3. Mol Pharmacol. 2006;70(1):340-7.

64. Monge-Nájera J. Editorial: Escorpiones de Costa Rica / Costa Rica scorpions. Rev Biol Trop. 2001;49(34):1293-4.

65. Gómez A, Bonilla F, Sasa M. Preliminary characterization of venoms from scorpion genera Centruroides and Tityus (Buthidae) from Costa Rica. In: Proceedings of the Tenth Meeting of the PanAmerican Section of the International Society on Toxinology; 2010 Apr 18-22; San José, Costa Rica. San José: International Society on Toxinology; 2010. 132 p.

66. Nishikawa AK, Caricati CP, Lima ML, Dos Santos MC, Kipnis TL, Eickstedt VR, et al. Antigenic crossreactivity among the venoms from several species of Brazilian scorpions. Toxicon. 1994;32(8):989-98.

67. Borges A. Los escorpiones y su veneno: ¿Por qué el veneno de los escorpiones puede ser mortal para el ser humano? In: Borges A, editor. Los escorpiones y el escorpionismo en Panamá. Panamá: Editora NovoArt; 2011. 21-30 p. 1 vol.

68. Baerg WJ. The effect of the venom of some supposedly poisonous arthropods of the Canal Zone (Centipede, Scorpion, Spider). Ann Entomol Soc Amer. $1925 ; 18(4): 471-82$.

69. Méndez E. Insectos y otros artrópodos de importancia médica y veterinaria. Panamá: Impresora Pacífico S.A.; 1999. 341 p.

70. Álvares ESS, Maria M, Amâncio FF, Campolina D. Primeiro registro de escorpionismo causado por Tityus adrianoi Lourenço (Scorpiones: Buthidae). Rev Soc Bras Med Trop. 2006;39(4):383-4.

71. McIntyre NE. Influences of urban land use on 
the frequency of scorpion stings in the Phoenix, Arizona, metropolitan area. Landscape Urban Plann. 1999;45(1):47-55.

72. Kant R, Acosta de Patiño H. Panamá. In: Organización Panamericana de la Salud, editors. Consulta técnica sobre accidentes con animales ponzoñosos en Latino América. São Paulo: OPS; 2007. 32-4 p.

73. Celis A, Gaxiola-Robles R, Sevilla-Godínez E, Orozco MJ, Armas J. Tendencia de la mortalidad por picaduras de alacrán en México, 1979-2003. Rev Panam Salud Pública. 2007;21(6):373-80.
74. Borges A, Miranda R, Pascale JM, Vega N, Acosta de Patiño H. Scorpions from the genus Tityus in Panamá: collection and maintenance, geographical distribution, and venom reactivity towards antivenoms. In: Proceedings of the $10^{\text {th }}$ Meeting of the PanAmerican Section of the International Society on Toxinology; 2010 Apr 18-22; San José, Costa Rica. San José: International Society on Toxinology; 2010. $161 \mathrm{p}$.

75. Guerrero-Vargas JA, Mourão CB, QuinteroHernández V, Possani LD, Schwartz EF. Identification and phylogenetic analysis of Tityus pachyurus and Tityus obscurus novel putative Na-channel scorpion toxins. PLoS One. 2012;7:e30478. 